\title{
公立八鹿病院 中央放射線部
}

\author{
○上仲彰洋 \\ Kaninaka Akihiro \\ 小谷康仁 \\ Kodani Yasuhito
}

【目的】当院の上部消化管撮影は、従来システム (Screen Fuji HG-H/Filn Kodak [EF/RA 撮影管電压80kV) で行っている が、音正条件からはずれると画質の低下を招き、投いうらいといった欠点がある。今回、その欠点を啝和する目的で同程度 の線量を前提に、ScreenのBackを一定とし、Front及ひ撮影管電代を変化させたシステムと従来システムとを物理的、視覚的 評你で比較検討を行った。

【方法】検討を行うシステムの組み合わせをTable 1に示す。I，物理的謤值

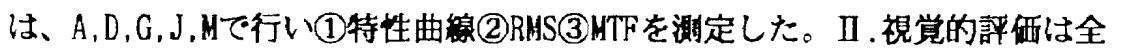
システムにおけるマーゲンファントムの椎体漫度が同じになるように撮影し、 詻癔故射線技師10名、放射線科医2名にて、バリウムの薄層部分、胃小湾倒と 椎体の重なる部分、胃小区、大祭例、全体像においてコントラスト、鲜鋭度、 粒状度、解像度について従来システムを基準とし、どちらが優れているかで比校した。

\begin{tabular}{|c|c|c|c|c|c|}
\hline & nownos & $150 / 400$ & 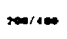 & seicus & 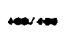 \\
\hline mar & ^ & - & 。 & , & - \\
\hline mor & - & ' & " & ' & " \\
\hline inear & $c$ & ' & , & I & o \\
\hline
\end{tabular}

Table 1

【結果】I（11においてG.Fogは、全てにおいてほほ同し值の橡0.23だった。GとJ、DとM及びAが平均階調度、感度で相似した (Fig 1)。(2)ではAが劣っていた(Fig 2)。(3)では全周波数領域においてAが優れていた(Fig 3)。II.H-GM Screenでは、Aが最 も良好で、撮影管電圧が高くなるにつれて画質の低下を招いた(Fig 4)。撮影管電圧による違いを各システムことにまとめる と、150で解像度においてE、Fが憂れていた。200ではGが比校的良好で、次いでHであった。250はほほ全項目において少って いた。400は全体澛の解度において良かったか、他は少っていた(Fig 5)。

【考察及びまとめ】物理的評任の特性曲線で200と250、150と400及びHG-Mが平均階調度之感度で相似した。MTFは全周波数領 域においてHG-Hが優れていた。RHSはHG-Mが劣り、他は相似していた。視覚的語任で撮影管電圧を变化させ各システムを比整 すると、撮影管電圧 $80 \mathrm{kV}$ のHG-Hが最も良い結果となりぜロクロスオーバー奻果を最大限に生かせるシステムだった。しかし、 全体像の解像度においては評価が低かった。このことは政稩部の描出には卓越しているが全体像を捕らえた時、コントラス トのつきすきた像として受け止められてしまい評俩が低くなったと考える。このことが报いずらいといった欠点となってい る。以上の事よりFront 200/Back 400の組み合わせで、撮影管電圧80 90kVか、従来システムの長所を生かし、短所を禣っ たシステムたと考える。

【結語】ScreenのBackを一定としFrontを変化させた組み合わせを比較 検討した耛果、撮影管電珐80kV Front Kodak Insight 200、Back Tosh iba T0400で良好な結果を得た。Screen の組み合わせを变化させることにより、 従来システムの欠点を䪔いより上部 消化管撮影に暗したシステムうくりが 可能となった。

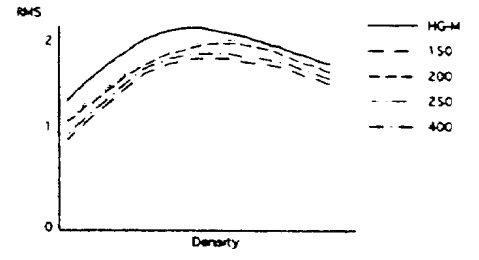

Fig 2

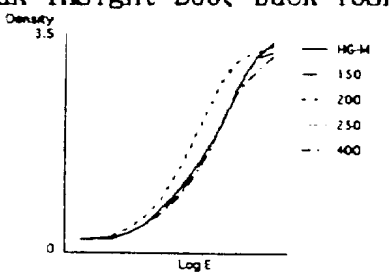

Fig 1

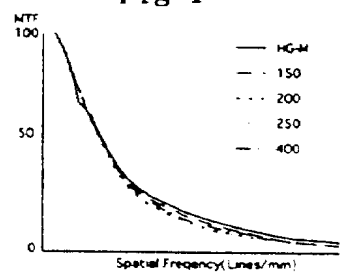

Fig 3

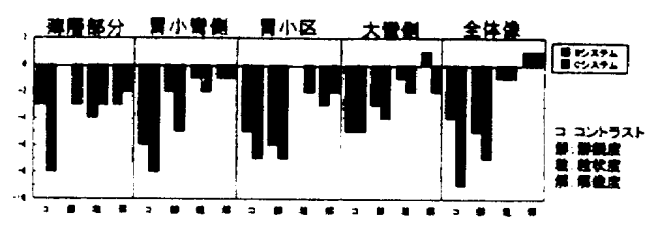

Fig 4

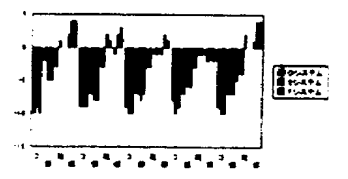

$150 / 400$

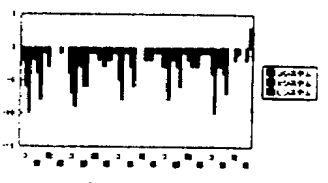
$250 / 400$
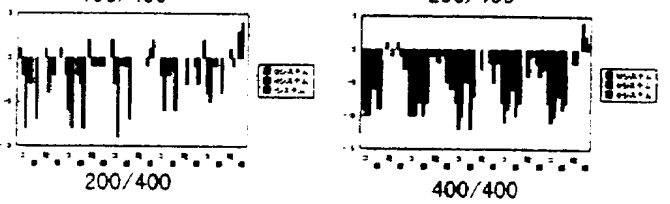

Fig 5 